\title{
Study of lactose / $\beta$-lactoglobulin interactions during storage
}

\author{
Marie THOMAS, Joël SCHER*, Stéphane DESOBRY \\ Laboratoire de Physico-chimie et Génie Alimentaires, ENSAIA-INPL, 2 avenue de la Forêt de Haye, \\ BP 172, 54505 Vandœuvre-lès-Nancy, France
}

Published online 24 June 2005

\begin{abstract}
The objective of this study was to evaluate the interactions between lactose and $\beta$-lactoglobulin in $\beta$-lactoglobulin/lactose powders (BL powders) during storage. Model BL powders were produced by co-lyophilization of lactose with increasing quantities of $\beta$-lactoglobulin. Lyophilization produced lactose in the amorphous state, which is highly reactive and likely leads to agglomeration of industrial whey powders. The BL powders were stored at $20 \pm 1{ }^{\circ} \mathrm{C}$ from 0.11 to $0.95 \mathrm{a}_{\mathrm{w}}$ and their water sorption behaviour was studied gravimetrically. Before storage, BL powders were amorphous. After storage at high $\mathrm{a}_{\mathrm{w}}$, a loss of water was observed on the moisture sorption isotherms of BL powders due to lactose crystals formation, detected by DSC and SEM analysis, and to the structural collapse of the powders. Lactose crystallization occurred at $a_{w}=0.43$ in pure lactose samples and at $\mathrm{a}_{\mathrm{w}}=0.59$ in BL powders containing $40 \% \beta$-lactoglobulin. Moreover, $\beta$-lactoglobulin was responsible for a delayed crystallization process in BL powders. Thus, the water sorption behaviour of BL powders was very different from the behaviour of the two compounds mixed after separate lyophilization $(\mathrm{B}+\mathrm{L}$ powders). These results pointed out interactions between lactose and $\beta$-lactoglobulin, which occurred during the lyophilization process and storage. Lactose/ $\beta$-lactoglobulin interactions stabilized the BL powders against lactose crystallization. In the last part of the work, the nature of the interactions (covalent links, $\mathrm{H}$ bonds and hydrophobic links) and the kinetic aspect of the crystallization were studied.
\end{abstract}

\section{whey powder / lactose / $\beta$-lactoglobulin / interaction / storage}

Résumé - Étude des interactions lactose/ $\beta$-lactoglobuline lors de la conservation. Les poudres obtenues à partir de lactosérum sont très souvent utilisées comme ingrédients alimentaires car elles possèdent d'intéressantes propriétés fonctionnelles (moussantes, gélifiantes...). Lors de la conservation de ces poudres, de nombreuses dégradations biologiques et physico-chimiques altèrent les propriétés fonctionnelles des produits, ainsi que les propriétés physiques et l'aspect des poudres (écoulement, couleur...). La stabilité de ces poudres dépend également fortement de la température de conservation ainsi que de l'activité de l'eau $\left(\mathrm{a}_{\mathrm{w}}\right)$ et de la composition des produits. Des poudres modèles ont été préparées par co-lyophilisation de lactose avec des quantités croissantes (10 à $40 \%$ ) de $\beta$-lactoglobuline (poudres $\mathrm{BL}$ ). Les poudres ont été conservées 3 mois à $20 \pm 1^{\circ} \mathrm{C}$, à des activités de l'eau comprises entre 0,11 et 0,95 . L'objectif de notre étude a été d'évaluer la présence ou l'absence d'interactions entre lactose et $\beta$-lactoglobuline lors de la conservation des poudres, en considérant le comportement de sorption d'eau de ces poudres. Les courbes isothermes de sorption d'eau des poudres BL ont été établies. Elles indiquent que toutes les poudres contenant du lactose libèrent de l'eau, mais à des $\mathrm{a}_{\mathrm{w}}$ différentes selon la teneur en $\beta$-lactoglobuline : à $\mathrm{a}_{\mathrm{w}}=0,43$ pour le lactose, à $\mathrm{a}_{\mathrm{w}}=0,54$ pour les poudres contenant 10 à $30 \%$ de $\beta$-lactoglobuline, et $\mathrm{a}_{\mathrm{w}}=0,59$ pour les poudres à $40 \%$ de $\beta$-lactoglobuline. Des analyses thermiques différentielles et des observations de microscopie électronique à balayage ont alors été effectuées pour vérifier que la libération d'eau dans les poudres BL est bien due à la cristallisation du lactose. Les comportements de sorption d'eau des

\footnotetext{
* Corresponding author: Joel.Scher@ensaia.inpl-nancy.fr
} 
poudres BL ont été comparés avec ceux de mélanges de lactose et de $\beta$-lactoglobuline lyophilisés séparément $(\mathrm{B}+\mathrm{L})$. Il a été montré qu'il y avait additivité des comportements de sorption d'eau dans les poudres mélangées séparément, mais pas dans les poudres co-lyophilisées ; ceci signifie que lactose et $\beta$-lactoglobuline ont interagi. Les interactions stabilisent les poudres BL en reportant l' $\mathrm{a}_{\mathrm{w}} \mathrm{de}$ cristallisation. Ce travail précise également la nature de ces interactions. En effet, des mesures de couleur ainsi que des mesures par spectroscopie infrarouge ont montré le développement de liaisons covalentes ainsi que des liaisons hydrogènes et hydrophobes entre les deux composants.

poudre sérique / lactose / $\beta$-lactoglobuline / interaction /conservation

\section{INTRODUCTION}

In 2003, 2 million tons of spray-dried whey protein were produced worldwide. Whey powders and derivatives are mainly used as food ingredients due to their interesting functional properties. Changes in lactose state occur during storage from the amorphous to the crystalline state [17]. When whey is spray-dried, lactose is mainly in the crystalline state but a small percent of amorphous lactose still exists and crystallizes during storage when temperature and/or humidity increase above glass transition ( $\mathrm{Tg}$ ), and leads to caking. Other physico-chemical alterations occur above $\mathrm{Tg}$, such as collapse, non-enzymatic browning and lipid oxidation [16]. So, it is essential to limit or control amorphous lactose crystallization to preserve spray- or freeze-dried powders.

According to Jouppila and Roos [9], proteins seem to limit or retard milk powder crystallization. Costantino et al. [6] showed that interaction between proteins and lactose modify lactose crystallization kinetics. In addition, lactose is known to have an efficient cryo-protector due to lactose-protein hydrogen bonds, which could also act to reduce crystallization kinetics [1].

The aims of the present work were to study the effects of $\beta$-lactoglobulin on lactose crystallization during storage of model "amorphous lactose/ $\beta$-lactoglobulin" powders (BL powders) and to study the interactions between these two compounds.

\section{MATERIALS AND METHODS}

\subsection{Preparation of the $B L$ powders}

Amorphous systems were obtained by freeze-drying solutions of lactose, $\beta$-lactoglob- ulin and the two compounds at different ratios. Solutions of $10 \%$ (w/v) $\alpha$-monohydrate lactose (Prolabo, Paris, France) and $\beta$-lactoglobulin (Davisco, Eden Prairie, USA) were prepared in distilled water. The solutions were stirred until complete dissolution. The $\mathrm{pH}$ of the lactose solution was 4.07 and the $\mathrm{pH}$ of all solutions containing $\beta$-lactoglobulin was between 7.30 and 7.56. The solutions were mixed to obtain $\beta$-lactoglobulin/lactose (BL) ratios of (10:90), (20:80), (30:70) and (40:60). Solution samples of $75 \mathrm{~mL}$ were immediately dispensed into $500-\mathrm{mL}$ round-bottomed flasks and quickly frozen at $-30{ }^{\circ} \mathrm{C}$ in a refrigerating bath. Frozen samples were stored at $-30^{\circ} \mathrm{C}$ for at least $12 \mathrm{~h}$ and then freeze-dried for $48 \mathrm{~h}$ using a Lyovac GT3 (Leybold-Heraeus, Orsay, France). The powders were stored in vacuum desiccators over $\mathrm{P}_{2} \mathrm{O}_{5}$ at $20{ }^{\circ} \mathrm{C}$ for one week to complete the dehydration.

The powders composed of the two compounds were assigned as BL(10:90), BL(20:80), BL(30:70) and BL(40:60).

\subsection{Storage of the BL powders and moisture sorption isotherms}

Samples were stored at $20 \pm 1{ }^{\circ} \mathrm{C}$ for 3 months over the saturated salt solutions ( $\mathrm{LiCl}, \mathrm{CH}_{3} \mathrm{COOK}, \mathrm{MgCl}_{2}, \mathrm{NaI}, \mathrm{K}_{2} \mathrm{CO}_{3}$, $\left.\mathrm{Mg}\left(\mathrm{NO}_{3}\right)_{2}, \mathrm{NaBr}, \mathrm{KCl}, \mathrm{KNO}_{3}\right)$. The solutions corresponded to water activity $\left(\mathrm{a}_{\mathrm{w}}\right)$ ranging from 0.11 to 0.95 , [8].

Approximately $0.5 \mathrm{~g}$ of powder samples were placed at each $\mathrm{a}_{\mathrm{w}}$. Two replicates were done. The moisture sorption was monitored gravimetrically. Moisture sorption isotherms were drawn up from the percentage of water adsorbed at each water activity ( $\mathrm{g}$ water $100 \mathrm{~g}^{-1}$ dry solid) when equilibrium was reached. 


\subsection{Differential Scanning Calori- metry (DSC)}

The state of lactose in BL powders was determined using a DSC analysis system (Pyris 1 and Pyris manager 2.0 software, Perkin Elmer, Norwalk, USA). The instrument was calibrated using indium. Analysis involved $50-\mu \mathrm{L}$ open aluminium pans (Perkin Elmer) containing powder samples of 3 to $5 \mathrm{mg}$. An empty pan was used as a reference. Two replicates of each sample were analyzed. Each sample was heated at a temperature rate of $10^{\circ} \mathrm{C} \cdot \mathrm{min}^{-1}$ in a temperature range from 25 to $250{ }^{\circ} \mathrm{C}$.

\subsection{Scanning Electron Microscopy (SEM)}

Samples of the moisture sorption equilibrium were used for SEM investigation. Thin layers of powder samples were mounted on aluminium stubs using a double-sided adhesive tape. The mounted samples were first sputter-coated with carbon and then with gold/palladium. The coated samples were examined with a Hitachi S2500 scanning electron microscope (Hitachi, Tokyo, Japan) operating at $17 \mathrm{kV}$ accelerating voltage.

\subsection{Color measurement}

The $b$ index, corresponding to the "blueyellow" axis in the L,a,b system, was measured with a microflash ${ }^{\circledR} 200 d$ (Datacolor international, Lawrenceville, USA) apparatus, on the model powders initially and after two months of storage at various water activities. All results were the mean of triplicate measurements.

\subsection{Infrared spectroscopy}

One hundred mg of powder was mixed $(15 \% \mathrm{w} / \mathrm{w})$ with anhydrous $\mathrm{KBr}$, which does not absorb infrared rays. By scanning IR wavelength from 4000 to $400 \mathrm{~cm}^{-1}$, and using a Fourier transform IR spectrometer IFS 55 (Bruker, Paris, France), around 200 absorption spectra were accumulated for each sample with a $2-\mathrm{cm}^{-1}$ resolution. First, oxygen and carbon dioxin spectra were deduced from the powder spectra and the resulting spectra were analyzed using Origin version 6.1 software. Second, spectra were smoothed using the 4th-order SavitzkyGolay algorithm. And then, second-order derivatives of the spectra were used to highlight interaction bands.

\section{RESULTS AND DISCUSSION}

\subsection{Moisture sorption isotherms and determination of the state of lactose in $B L$ powders}

The moisture sorption isotherms of lactose, $\beta$-lactoglobulin and BL powders containing the two compounds are shown in Figure 1. $\beta$-Lactoglobulin had a sigmoid moisture sorption isotherm, which is typical of food proteins. Pure $\beta$-lactoglobulin powder was very hygroscopic and adsorbed more water than the other powders studied. In BL powders above $0.70 \mathrm{a}_{\mathrm{w}}$, the higher the $\beta$-lactoglobulin content, the more the powder adsorbed water.

Isotherms of all powders containing lactose were irregular between $0.39 \mathrm{a}_{\mathrm{w}}$ and $0.55 \mathrm{a}_{\mathrm{w}}$ : they released water and their sorption isotherms thus showed a "break", corresponding to high water release. This water release occurred at higher $\mathrm{a}_{\mathrm{w}}$ with increasing $\beta$-lactoglobulin content in $\mathrm{BL}$ powders. Pure lactose powder released water at $0.39 \mathrm{a}_{\mathrm{w}}$. BL powders with 10 to $30 \% \beta$-lactoglobulin released water at $0.43 \mathrm{a}_{\mathrm{w}}$. The sorption isotherms of BL(40:60) with $40 \% \beta$-lactoglobulin only showed a "break" at $0.55 \mathrm{a}_{\mathrm{w}}$. According to the literature, the release of water by powders containing lactose is due to lactose crystallization $[2,5,9]$. Water is released when the hygroscopic amorphous lactose crystallizes into the less hygroscopic crystalline forms.

The characterization of the lactose state in the lyophilized powders, before and after storage, was undertaken using differential scanning calorimetry (DSC). Before storage, lyophilized lactose samples were amorphous. The DSC curves of lyophilized lactose showed an exothermic peak at around $175^{\circ} \mathrm{C}$ and an endothermic peak at $218{ }^{\circ} \mathrm{C}$ (Fig. 2). These peaks correspond to 


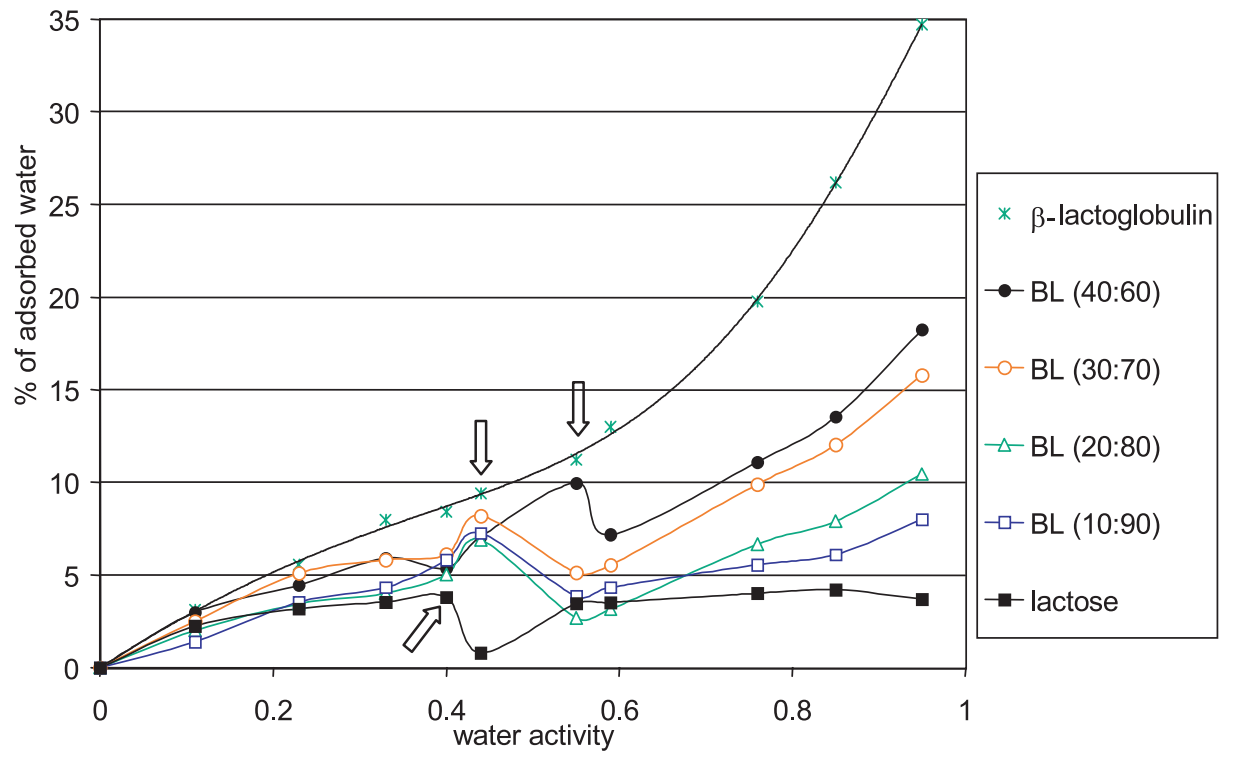

Figure 1. Moisture sorption isotherms of all lyophilized powders after 12 weeks of storage. The three arrows on the graph indicate a sharp water loss, respectively, from lactose above $0.39 \mathrm{a}_{\mathrm{w}}$; from BL(10:90), BL(20:80), BL(30:70) above $0.43 \mathrm{a}_{\mathrm{w}}$; and from BL(40:60) above $0.55 \mathrm{a}_{\mathrm{w}}$.

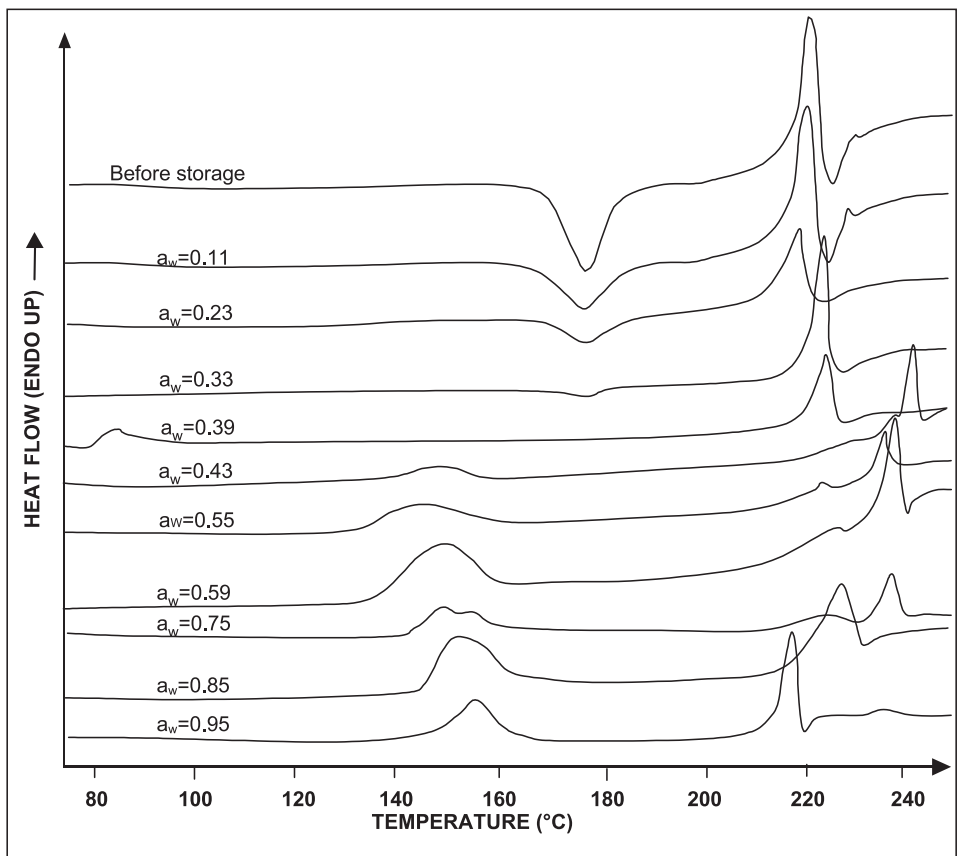

Figure 2. DSC profiles of lyophilized lactose samples before and after 3 months of storage at water activities between 0.11 and 0.95 at $20^{\circ} \mathrm{C}$. 


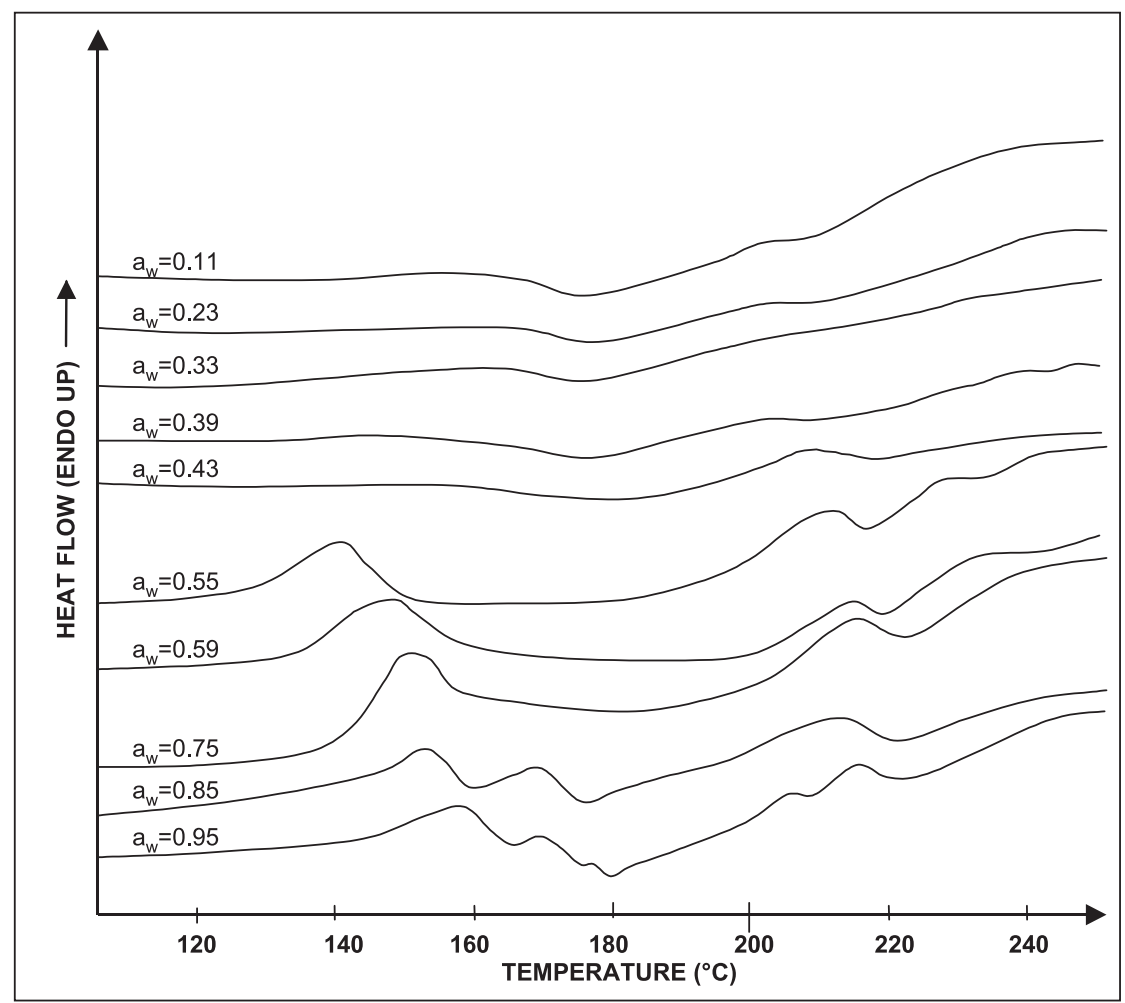

Figure 3. DSC profiles of BL(10:90) after 3 months of storage at $a_{w}$ between 0.11 and 0.95 at $20{ }^{\circ} \mathrm{C}$.

the re-crystallization of amorphous lactose during analysis, and to the melting of the crystalline $\alpha$-lactose produced, respectively [10].

After storage at $\mathrm{a}_{\mathrm{w}}$ below 0.39 , lactose remained amorphous, as shown by the exothermic peaks still present. On the contrary, for $\mathrm{a}_{\mathrm{w}}$ above 0.43 , an endothermic peak appeared at $150{ }^{\circ} \mathrm{C}$, showing the presence of $\alpha$-monohydrate lactose crystals. Lactose storage at $\mathrm{a}_{\mathrm{w}} \geq 0.43$ led to lactose crystallization.

DSC profiles for BL powders are much more complex due to the endothermic profile of $\beta$-lactoglobulin which covers the endothermic and exothermic peaks (Fig. 3). Comparison of DSC profiles of the BL(10:90) powder showed that the peak of water release from $\alpha$-monohydrate lactose crystals $\left(150^{\circ} \mathrm{C}\right)$ and the peak of crystals melt- ing (above $200{ }^{\circ} \mathrm{C}$ ) appeared for $\mathrm{a}_{\mathrm{w}} \geq 0.54$. Amorphous lactose was stable up to $\mathrm{a}_{\mathrm{w}}=0.43$, and crystallization appeared above this water activity. The same observation was made for the BL(20:80) and BL(30:70) powders. Considering the powder with $40 \%$ of $\beta$-lactoglobulin, crystallization appeared only at $\mathrm{a}_{\mathrm{w}}=0.59$.

Scanning electron microscopy was used as a complementary technique to confirm the DSC analysis of BL powders, especially with high $\beta$-lactoglobulin content. Micrographs (Figs. 4a and 4b) show particles of BL(10:90) stored for 3 months at 0.23 and $0.54 \mathrm{a}_{\mathrm{w}}$.

The particles of all powders studied had miscellaneous, irregular size and shape. However, the surfaces of all the particles were very smooth, which is characteristic of amorphous systems [11]. The critical water 

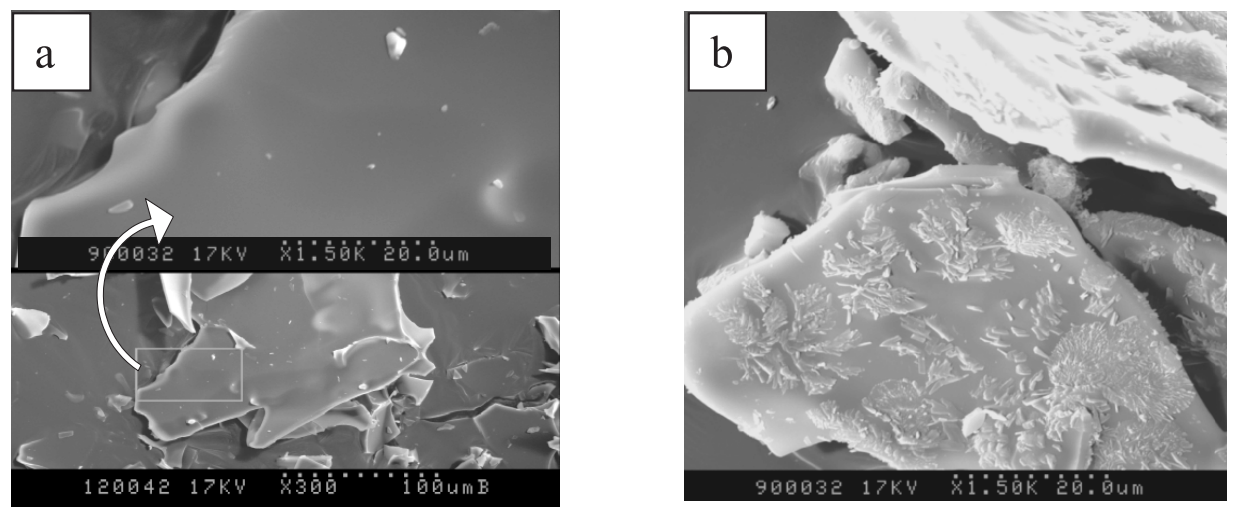

Figure 4. Scanning electron micrographs of $\mathrm{BL}(10: 90)$ stored for 3 months at $20{ }^{\circ} \mathrm{C}$ and 0.23 (a) and 0.54 (b) $\mathrm{a}_{\mathrm{w}}$. (x1000 magnification).

activity of crystallization was determined from the micrographs. Below this critical $\mathrm{a}_{\mathrm{w}}$, particle surfaces were smooth, since lactose remained amorphous. Above the critical $\mathrm{a}_{\mathrm{w}}$, lactose crystals clearly appeared on particle surfaces. The critical $\mathrm{a}_{\mathrm{w}}$ of crystallization was 0.43 in lactose powders and 0.55 in BL powders containing 10 to $30 \%$ $\beta$-lactoglobulin. The critical $a_{w}$ of BL(40:60) with $40 \% \beta$-lactoglobulin was 0.59 , since lactose crystals were observed on particle surfaces only at this $\mathrm{a}_{\mathrm{w}}$ and above.

The SEM analysis was consistent with the results obtained from moisture sorption isotherms and DSC analysis. BL powders were stabilized against lactose crystallization. In BL powders containing from 10 to $30 \% \beta$-lactoglobulin, lactose crystallization was delayed to $0.55 \mathrm{a}_{\mathrm{w}}$ and BL powders with $40 \% \beta$-lactoglobulin were stabilized until $0.59 \mathrm{a}_{\mathrm{w}}$.

Besides, it has been shown [15] that for contents higher than $5 \%$ of $\beta$-lactoglobulin in the powders, $\mathrm{pH}$ has no significant effect (buffer effect of the protein) either on sorption isotherms or on IR spectra.

\subsection{Lactose/ $\beta$-lactoglobulin interactions}

The moisture sorption isotherms of powders mechanically mixed after separate lyophilization were drawn up and were com- pared with the corresponding theoretical curves calculated from the sorption isotherms of lyophilized lactose and $\beta$-lactoglobulin.The sorption isotherm corresponding to the BL(10:90) powder is representative of all the $\beta$-lactoglobulin/lactose ratios studied (Fig. 5).

The water sorption curves of B + L powders (with the two components lyophilized separately) were similar to the theoretical curves. The behavior of water sorption of these mixed powders corresponded to the addition of the behavior of each compound taken separately, neglecting $\beta$-lactoglobulin/lactose interaction. Lactose crystallization occurred at the water activity predicted from individual lactose and $\beta$-lactoglobulin powders. Contrary to the mixed powders, the BL powders had specific sorption curves, which differed from the theoretical curves, especially between $0.39 \mathrm{a}_{\mathrm{w}}$ and $0.60 \mathrm{a}_{\mathrm{w}}$. BL powders adsorbed more water than predicted, at the $\mathrm{a}_{\mathrm{w}}$ before lactose crystallized. Moreover, in BL powders, water release during lactose crystallization clearly occurred at higher $a_{w}$ than predicted. The obvious differences between theoretical and experimental moisture sorption isotherms of BL powders showed evidence of solidstate interaction between lactose and $\beta$-lactoglobulin. These molecular interactions stabilized BL powders against lactose crystallization. Jouppila and Roos [9] noticed 


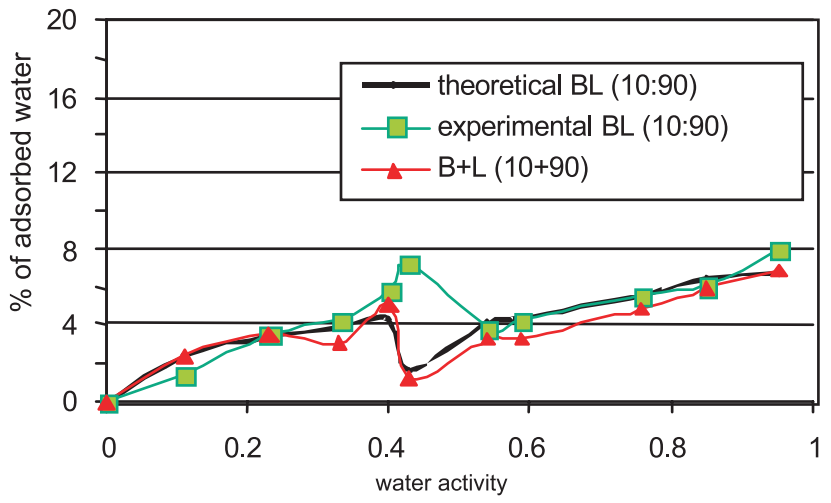

Figure 5. Theoretical and experimental moisture sorption isotherms of $\mathrm{BL}(10: 90)$ after 9 weeks of storage. Theoretical curves were calculated from the moisture sorption isotherms of each component considered separately. $\mathrm{B}+\mathrm{L}$ powders were composed of lactose and $\beta$ lactoglobulin mixed after separate lyophilization.

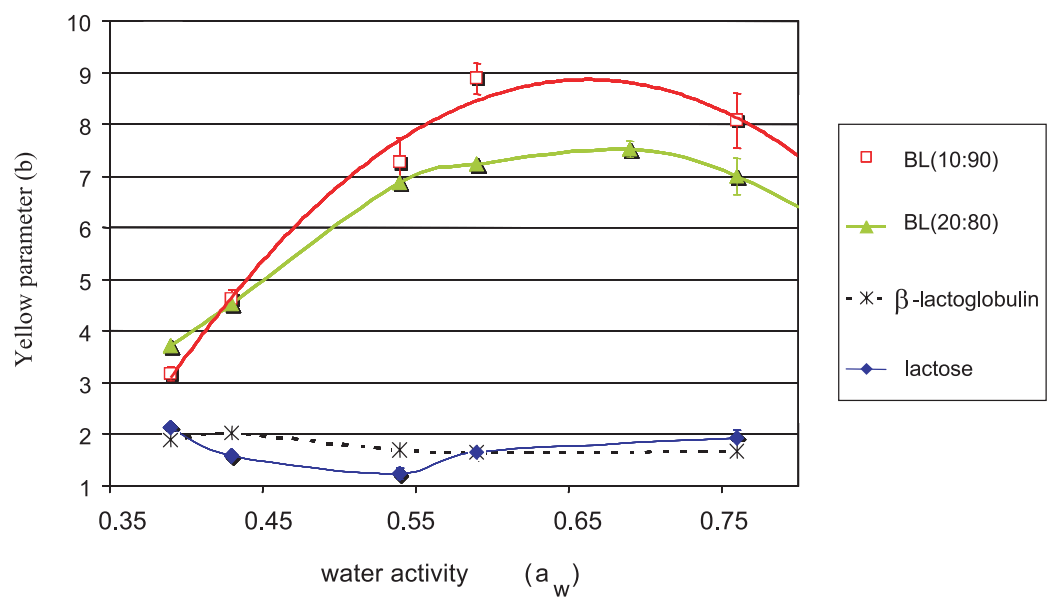

Figure 6. Browning of $\beta$-lactoglobulin, lactose and model BL powders after 2 months at $20^{\circ} \mathrm{C}$.

a delayed crystallization of lactose in milk powders compared with pure lactose and they reported that milk proteins could be responsible for this phenomenon. Although suspected, the result we obtained for BL powders was, to our knowledge, not clearly demonstrated between two milk components.

\subsubsection{Covalent interactions}

The coloring parameter $b$ was followed for two months in the powders stored at $\mathrm{a}_{\mathrm{w}}$ from 0.39 to $0.76[13,14]$. The $b$ parameter (Fig. 6) of pure lactose and pure $\beta$-lactoglobulin did not vary for any storage water activity, and showed that non-enzymatic browning (NEB) did not occur in the pure powders. For BL(10:90) and BL(20:80), the $b$ parameter significantly changed during storage. For $\mathrm{a}_{\mathrm{w}}$ between 0.39 and 0.69 , the more the $a_{w}$ increased, the more $b$ increased. For $a_{w}>0.69$, b changes were slowed; this reduction corresponds to a modification of the structure of the powder (collapse). This was a typical observation corresponding to NEB in powders and $b$ changes were in complete agreement with the NEB kinetic profile proposed by Labuza [10] for NEB. The yellowing of the powders corresponded to the Maillard reaction. 


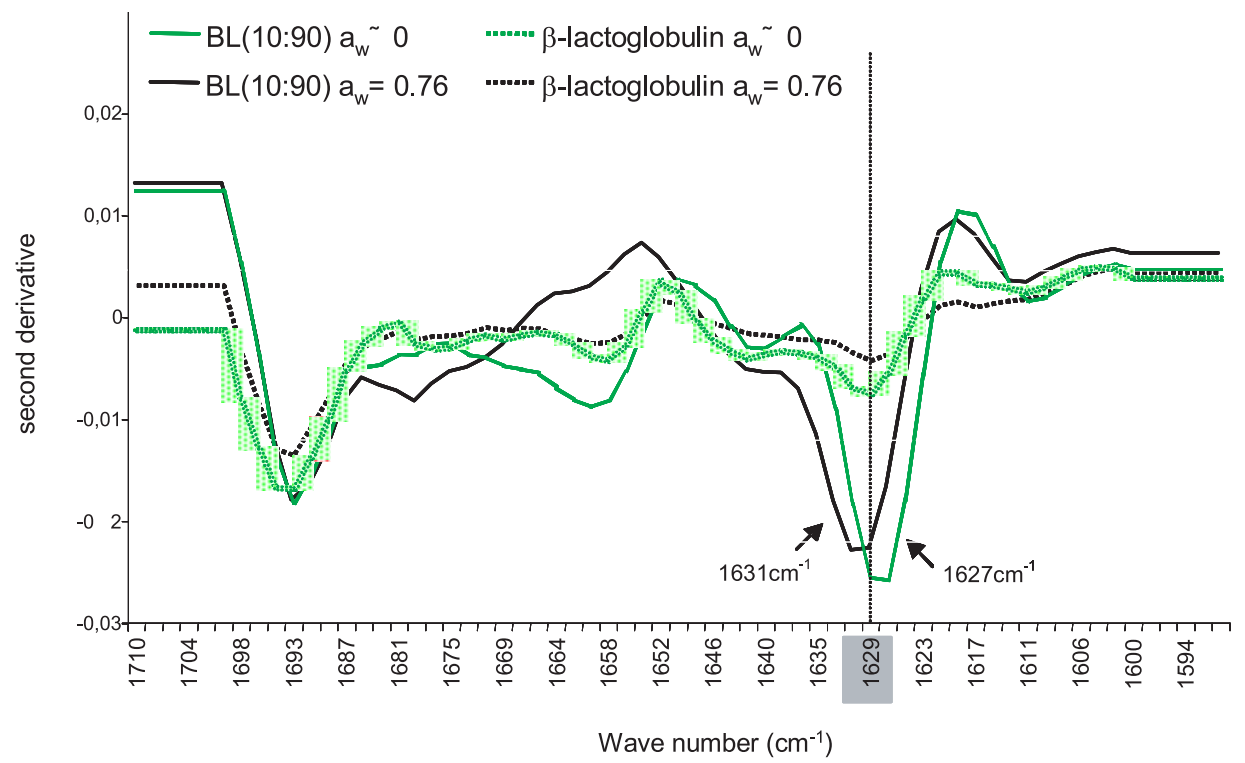

Figure 7. Mid-Infrared Spectroscopy: second-derivative spectra of samples stored for 3 weeks at $20^{\circ} \mathrm{C}$ at $\mathrm{a}_{\mathrm{w}} \approx 0$ and 0.76 . Lactose absorbance was subtracted. The amide I band of spectra was smoothed and normalized before derivation. The peak at $1629 \mathrm{~cm}^{-1}$ is attributed to the $\beta$ sheet structure of $\beta$-lactoglobulin.

\subsubsection{Non-covalent interactions}

Non-covalent interactions between lactose and $\beta$-lactoglobulin were studied by IR spectroscopy $\left(4000-400 \mathrm{~cm}^{-1}\right)$. Freezedried lactose, $\beta$-lactoglobulin and BL(10:90) powders were analyzed after two months of storage at several $\mathrm{a}_{\mathrm{w}}$. Figure 7 shows the second derivative of the IR spectra of pure $\beta$-lactoglobulin and mixed powder BL(10:90) stored at $\mathrm{a}_{\mathrm{w}}=0.76$. Analyses of all spectra showed that lactose crystallization led to changes in the vOH band, which moved to lower wavenumbers, and the band became thinner. These changes resulted from the increase in the number of hydrogen bonds during crystallization.

In the co-lyophilized model powders stored at $\mathrm{a}_{\mathrm{w}}=0, \beta$-lactoglobulin presented a high amount of hydrogen bonds with lactose, as shown by the low wavenumber of the amide I band and $\beta$-sheet. These interactions stabilized the $\beta$-sheet structure of the $\beta$-lactoglobulin. These effects did not appear in the powders mixed after lyophilization.
Model powder BL(10:90) stored at $\mathrm{a}_{\mathrm{w}}=0.43$ showed a high number of hydrogen bonds due to hydration, but also hydrophobic inter- $\beta$-sheets and $\beta$-lactoglobulin/ lactose links. These hydrophobic links led to the increase in $\beta$-lactoglobulin thermal resistance $[3,4,7]$. The energy levels of the hydrophobic interactions ( 1 to $3 \mathrm{kcal} \cdot \mathrm{mol}^{-1}$ ) are lower than hydrogen bonds (2 to $10 \mathrm{kcal} \cdot \mathrm{mol}^{-1}$ ) [12] and are more difficult to measure by IR spectroscopy.

For the model powders stored at $\mathrm{a}_{\mathrm{w}}=0.76$, advanced lactose crystallization reduced the number of $\beta$-lactoglobulin/lactose links and increased the number of lactose/water hydrogen bonds.

\section{CONCLUSION}

In the present work, $\beta$-lactoglobulin was shown to increase the $\mathrm{a}_{\mathrm{w}}$ of lactose crystallization in co-lyophilized BL powders. This delayed critical $\mathrm{a}_{\mathrm{w}}$ was not observed in the powders mixed after lyophilization due to 
the greater physical distance between lactose and $\beta$-lactoglobulin molecules.

In the water sorption isotherms, no simple additivity of the lactose and $\beta$-lactoglobulin isotherms was observed, due to the competition between lactose and water to produce $\mathrm{H}$ bonds with $\beta$-lactoglobulin. The $\beta$-lactoglobulin/lactose interactions were shown to stabilize the lyophilized powder and increased the crystallization critical $\mathrm{a}_{\mathrm{w}}$. Moreover, IR spectroscopy analyses showed that hydrogen bonds stabilized the $\beta$-sheets even after hydrogen bond re-arranging due to lactose crystallization.

Color changes in the BL powders during storage showed that NEB occurred in the model powders, and the lactosylation process existed prior to browning.

\section{REFERENCES}

[1] Arakawa T., Prestrelski S.J., Kenney W.C., Carpenter J.F., Factors affecting short-term and long-term stabilities of proteins, Adv. Drug Deliv. Rev. 46 (2001) 307-326.

[2] Berlin E., Anderson B.A., Pallansch M.J., Water vapor sorption properties of various dried milks and wheys, J. Dairy Sci. 51 (1968) 1339-1344.

[3] Boye J.I., Alli I., Thermal denaturation of mixtures of $\alpha$-lactalbumin and $\beta$-lactoglobulin: a differential scanning calorimetric study, Food Res. Int., 33 (2000) 673-682.

[4] Cayot P., Lorient D., Structure et technofonctionnalités des protéines de lait, Tech et Doc Lavoisier, Paris, France, 1998.

[5] Corrigan D.O., Healy A.M., Corrigan O.I., The effect of spray-drying solutions of polyethylene glycol (PEG) and lactose/PEG on their physicochemical properties, Int. J. Pharm. 235 (2002) 193-205.

[6] Costantino H.R., Curley J.G., Wu S., Hsu C.C., Water sorption behaviour of lyophilized protein-sugar systems and implications for solid-state interactions, Int. J. Pharm. 166 (1998) 211-221.

[7] Dong A., Prestrelski S.J., Allison S.D., Carpenter J.F., Infrared spectroscopic studies of lyophilization- and temperature-induced protein aggregation, J. Pharm. Sci. 84 (1995) 415-424.

[8] Greenspan J., Humidity fixed points of binary saturated aqueous solutions, J. Res. Nat. Bureau Standards, section A: Physics and chemistry 81 (1977) 89-93.

[9] Jouppila K., Roos Y.H., Glass transition and crystallization in milk powders, J. Dairy Sci. 77 (1994) 2907-2915.

[10] Labuza T.P., Tannenbaum S.R., Karel M., Water content and stability of low-moisture and intermediate-moisture foods, Food Technol. 24 (1970) 35-42.

[11] Lai H.M., Schmidt S.J., Lactose crystallization in skim milk powder observed by hydrodynamic equilibria, scanning electron microscopy and ${ }^{2} \mathrm{H}$ nuclear magnetic resonance, J. Food Sci. 55 (1990) 994-999.

[12] Michot L.J., Villiéras F., François M., Bihannic I., Pelletier M., Cases J.M., Water organisation at the solid-aqueous solution interface, C. R. Geosci. 334 (2002) 611-631.

[13] Nielsen B.R., Stapelfeldt H., Skibsted L.H., Early prediction of the shelf-life of mediumheat whole milk powders using stepwise multiple regression analysis, Int. Dairy J. 7 (1997) 341-348.

[14] Stapelfeldt H., Nielsen B.R., Skibsted L.H., Effect of heat treatment, water activity and storage temperature on the oxidative stability of whole milk powder, Int. Dairy J. 7 (1997) 331-339.

[15] Thomas M.E.C., Influence de l'activité de l'eau sur les interactions lactose/ $\beta$-lactoglobuline de poudres laitières modèles lyophilisées, Thèse de l'INPL, Nancy, France, 2004.

[16] Thomas M.E.C., Scher J., Desobry S., Milk powders ageing: effect on physical and functional properties, Crit. Rev. Food Sci. Nutr. 44 (2004) 297-322.

[17] Vuataz G., The phase diagram of milk: a new tool for optimising the drying process, Lait 82 (2002) 485-500. 